\title{
CRM Pricing Research of China's Inter-bank
}

\author{
Guiyun YOU \\ School of Economics \\ Ocean University of China \\ Qingdao, China, +86-0532-66782130 \\ Email:youguiyun0330@yahoo.com.cn
}

\author{
Siying HAN \\ Eller Management School \\ University of Arizona \\ Arizona, U.S \\ Email:hansiying1210@g mail.com
}

\author{
Zheng LIU \\ School of Insurance and Economics \\ University of International Business and \\ Economics \\ Beijing, China, +86-010-64493158
}

\begin{abstract}
Credit risk mitigation (CRM) is an effective mean for bank's credit risk transformation. Buying CRM can reduce bank's capital requirement, and meet Basel regulatory agreement effectively. China's implementation of CRM will help improve the credit risk-sharing mechanisms, solve the "paradox of credibility" effectively and raise the proportion of direct financing. In this paper, the idea of credit spread is used to price CRM, in which the main parameters processed by KMV model. Through pricing 11 Agriculture CP01 CRM, this paper provides some references for China's CRM pricing research.
\end{abstract}

\section{Keywords-Credit risk mitigation; Credit spread; KMV}

\section{INTRODUCTION}

Derivative market embraced its boom from 1990s in western developed countries. Although in some level, the over speculation and lack of inspection lead to the recent financial crisis, the derivative market is important to a robust financial market. And it plays key roles in risk management for financial institutions. Compared to the prosperous derivative market in western developed countries, the derivative market in China is far behind in instrument diversity, market volume and innovation. Now, the loan market in China has a value of 40 trillion RMB, and in terms of whole value the bond market ranked as the second in Asia and sixth globally. However, there is no derivative that can be used for risk management effectively. The introduction of credit risk mitigation (CRM) tools is a breakthrough for this scenario. During 2011 and 2012, big commercial banks in China will apply Basel II (known as the New Basel Accord). The introduction of credit risk mitigation tools as a necessary premise to application of Basel II also will push this process. The pricing of CRM is essential and difficult point, and this paper can provide some theoretical guidance to derivative market in China.

\section{THE DEVELOPMENT OF CRM}

\section{A. Introduction and development globally}

CRM is the employment of various methods to reduce the risks to lenders, banks and other business which offercredit. The methods can include risk based pricing, or adjusting the cost of credit according to the credit strength of the borrower; credit tightening, or reducing the amount of credit available to higher risk applicants; diversification, or increasing the portfolio mix of borro wers and purchasing credit insurance.
With the development of risk management, Basel committee place more importance on CRM which is reflected in a series of rules and files as showed in Tab.I. The 2006 new capital accord recognized CRM as eligible capital which can substitute capital requirement by Basel Accord. This file determined eligible CRM and built comparably complete CRM management outline technically.

TABLE I. The Historical Evolution of the Credit Risk Mitigation Techniques

\begin{tabular}{|c|c|c|}
\hline Time & Title & Main content \\
\hline $\begin{array}{l}\text { Jul } \\
1988\end{array}$ & $\begin{array}{l}\text { International } \\
\text { convergence of capita } \\
\text { measurement and capita } \\
\text { standards }\end{array}$ & $\begin{array}{l}\text { Recognized the importance of } \\
\text { mortgage and guarantee to reduce } \\
\text { credit risk ; no agreeable standard } \\
\text { about eligible mortgage; no } \\
\text { discussion about the credit risk } \\
\text { mitigation effect of derivatives }\end{array}$ \\
\hline Jan & $\begin{array}{l}\text { Bank and other high } \\
\text { levered institution } \\
\text { trading guidance }\end{array}$ & $\begin{array}{l}\text { Banks need to be cautious about the } \\
\text { other risk mortgage brings when } \\
\text { mitigating credit risks. }\end{array}$ \\
\hline Jun & $\begin{array}{l}\text { New capital accord ( } \\
\text { draft for discussing) (the } \\
\text { first draft) }\end{array}$ & $\begin{array}{l}\text { Recognized risk management effec } \\
\text { of financial instruments excep } \\
\text { derivatives }\end{array}$ \\
\hline $\operatorname{Jan} 2001$ & $\begin{array}{l}\text { New capital accord } \\
\text { draft for discussing) (the } \\
\text { second draft) }\end{array}$ & $\begin{array}{l}\text { Introduced the credit mitigation tech } \\
\text { system; allowed banks to take the } \\
\text { mortgage into account when } \\
\text { calculating default rate }\end{array}$ \\
\hline Apr 2003 & $\begin{array}{l}\text { New capital accord (a } \\
\text { draft for discussing) (the } \\
\text { third draft) }\end{array}$ & $\begin{array}{l}\text { Detailed defined CRM; in internal } \\
\text { audit, banks can consider the } \\
\text { derivatives using internal ratings- } \\
\text { based approach }\end{array}$ \\
\hline Jun 2004 & $\begin{array}{l}\text { International } \\
\text { convergence of capita } \\
\text { measurement and capita } \\
\text { standards }\end{array}$ & $\begin{array}{l}\text { To perfect CRM tech system, there } \\
\text { are more specific requirement in } \\
\text { terms of mort gage, risk weight, } \\
\text { information disclosure and etc. }\end{array}$ \\
\hline Jun 2006 & New Basel Accord & $\begin{array}{l}\text { CRM are defined as mortgagec } \\
\text { guarantee, credit derivatives anc } \\
\text { netting settlement }\end{array}$ \\
\hline Dec 2009 & $\begin{array}{l}\text { Principle of } \\
\text { management } \\
\text { regulation }\end{array}$ & $\begin{array}{l}\text { Risk management using a serie } \\
\text { instruments }\end{array}$ \\
\hline
\end{tabular}

Source: filing released by the Bankfor International Settlements 


\section{B. Introduction and development in China}

On Oct 29, 2010 National Association of Financial Market Institutional Investors issued Interbank Market CRM Tools Trial Guidance (referred as Guidance later) and Derivatives Trade Agreement. In the Guidance, CRM is referred as Credit Risk Mitigation Agreement, Credit Risk Mitigation Warrant and other basic credit derivatives used in credit risk management. The underlying financial tools in CRM are bond and bond like instruments. Given the comple xity and high risk of credit derivatives, Gu idance only recognizes credit default swap and total return swap as eligible CRM and the debt in CRM must be the direct debt of the credit protection provider. It requires commercial banks use CRM for credit protection instead of profit. Also there are special requirements for the settling up and loss measurement.

From this we can see CRM in China is similar to Credit Default Swap (CDS) and Total Return Swap(TRS). So far, CRM is modified CDS according to Chinese specific circumstances and " $2+\mathrm{N}$ " innovation. CRMA and CRMW are two core products for CRM. CRMA is the simplified CDS and CRMW is the innovatively standardized CDS which can be traded in secondary market.

The following are differences between CRM and CDS:

- $\quad$ Simple structure. The existing products are based on interbank liquid bonds. The design of CRM does not suffer from complicated design such as pass -through.

- Clear underlying product. The underlying product must be a clear debt which avoids unclear mess up of assets.

- Pre-report and central clearing. Uniform reg is tration effectively controls the leverage. The central clearing avoids over speculation and over expansion of this market which keeps system risk from spreading.

- $\quad$ Based on the above analysis, CRM in China is a kind of credit insurance as CDS. So the pricing method of $\mathrm{CRM}$ is similar to that of CDS.

\section{CRM PRICING METHOD AND MODELPARAMETER}

\section{A. Pricing method}

The pricing model of CDS, dis counted future cash flow is a popular method. In this model, default probability, loss given default, and discount factor are important parameters. Given the complete default database for western developed countries, they can use the existing default data to value CDS. Or they can use structure model or reduced form model to price CDS. Bond and credit market in China started late, and CRM market is even a brand new thing. So the data for this market very limited which makes the discounted future cash flow method not appropriate, while credit spread method is easy to apply except it is not accurate. But the structure of CRM is simple, so credit spread method can be used here to price CRM or CDS. In this paper we use credit spread method to price CRM.
Generally, rate of return is negatively related to the credit rating grade of bonds. Low credit quality bond usually gives investor higher rate of return to compromise higher credit risk. Credit spread method uses the risk premium between different credit quality bonds of the same underlying entity. Bond holders can fix their rate of return buying CRM to transfer the risk. So the risk premium here is the price of CRM.

Price of CRM = Low quality bond rate of return - High quality bond rate of return (or risk free rate)

\section{Assume that:}

Risk free rate $r$; bond interest rate $i$, that is the price of bond; volume of bonds: $\mathrm{F}$; bond face value $\mathrm{F}_{\mathrm{T}}$; enterprise asset value: V; expected default rate EDF; expected default loss EL; term of bond T; CRM price $\omega$.

Under the assumption of no arbitrage, risk free bond has the same rate of return as risk bond.

$$
\mathrm{Fe}^{\mathrm{rT}}=\mathrm{Fe}^{\mathrm{iT}}(1-\mathrm{EDF})+\mathrm{EDF}\left(\mathrm{Fe}^{\mathrm{iT}}-\mathrm{EL}\right)
$$

$\mathrm{Fe}^{\mathrm{iT}}(1-\mathrm{EDF})$ is the return when debtor pays the claim; $\operatorname{EDF}\left(\mathrm{Fe}^{\mathrm{iT}}-\mathrm{EL}\right)$ is the return when debtor defaults;

$$
\begin{gathered}
\because \mathrm{F}_{\mathrm{T}}=\mathrm{Fe}^{\mathrm{iT}} \\
\therefore \mathrm{F}_{\mathrm{T}} \mathrm{e}^{-\mathrm{iT}} \mathrm{e}^{\mathrm{rT}}=\mathrm{F}_{\mathrm{T}}(1-\mathrm{EDF})+\operatorname{EDF}\left(\mathrm{F}_{\mathrm{T}}-\mathrm{EL}\right) \\
\mathrm{e}^{(\mathrm{r}-\mathrm{i}) \mathrm{T}}=1-\frac{\mathrm{EDF} \cdot \mathrm{EL}}{\mathrm{F}_{\mathrm{T}}} \\
\omega=\mathrm{i}-\mathrm{r}=-\frac{1}{\mathrm{~T}} \cdot \ln \left(1-\frac{\mathrm{EDF} \cdot \mathrm{EL}}{\mathrm{F}_{\mathrm{T}}}\right)
\end{gathered}
$$

As shown in (1), FT and T are known, EDF and EL are two important parameters in CRM pricing which are calculated by credit risk model in this paper.

\section{B. Model Parameter}

This paper follows KMV model to calcu late EDF and EL. $\mathrm{KMV}$ model is a credit risk model based on MM theory, Black-Scholes, and Merton model. In KMV model equity is treated as a call option on company asset. Default has the same effect as giving up the call option. The more the enterprise asset devalues, the higher the default risk, and the higher value the option has.

KMV model has several premises, and the most important one is the option pricing theory as shown below:

Assuming asset price follows logarithm normal distribution, and trading is consecutive and there is no trading fees, taxes, or paid bonus when the option is effective. Also the risk free rate is assumed to be a constant.

$$
\mathrm{E}=\mathrm{VN}\left(\mathrm{d}_{1}\right)-\mathrm{De}^{-\mathrm{r \tau}} \mathrm{N}\left(\mathrm{d}_{2}\right)
$$

Hereinto,

$$
\begin{gathered}
\mathrm{d}_{1}=\frac{\ln \left(\frac{\mathrm{V}}{\mathrm{D}}\right)+\left(\mathrm{r}+\frac{1}{2} \sigma_{\mathrm{A}}^{2}\right) \tau}{\sigma_{\mathrm{A}} \sqrt{\tau}} \\
d_{2}=d_{1}-\sigma_{A} \sqrt{\tau}
\end{gathered}
$$


$E$ is the price of call option, which is the equity value of a company; $\mathrm{D}$ is the market value of company bonds; $\tau$ is the term of bond; $\mathrm{r}$ is risk free rate; $\mathrm{V}$ is market value of enterprise asset, $\sigma_{A}$ is the volatility of asset value.

Also we also know that

$$
\sigma_{E}=\rho_{E, A} \sigma_{A}=\frac{V}{E} \cdot \frac{\partial E}{\partial V} \cdot \Delta \cdot \sigma_{A}
$$

$\sigma_{E}$ is the standard error of equity return; $\rho_{E A}$ is the elasticity of equity value to company asset; $\Delta$ is option hedge ratio, that is $\mathrm{N}\left(\mathrm{d}_{1}\right)$.

$$
\therefore \sigma_{E}=\frac{N\left(d_{1}\right) V}{E} \sigma_{A}
$$

From(3) and (4), we can get $\mathrm{V}$ and $\sigma_{A}$.

- $\quad$ Default point (DP)

One premise of KMV model is that the company will default when asset value is lower than such a level. This level is defined as default point. Based on more than 4,000 companies analysis, KMV company get the following formula of default point:

$$
\mathrm{DP}=\mathrm{STD}+0.5 \mathrm{LTD}
$$

STD is liquid debt and LTD is long term debt;

\section{- Default distance (DD)}

Default distance is how many standard errors it needs to devalue to default point. In KMV model, default distance is the indicator used to measure default risk. The higher the DD is, the higher ability company has to pay off debt and the lower credit risk the company has. The formula is as following:

$$
\mathrm{DD}=\frac{E(V)-D P}{E(V) \sigma_{A}}
$$

- $\quad$ Expected default frequency (EDF)

EDF is used to indicate the default probability of a company in the future in KMV model. The formula to calculate EDF:

$$
\begin{gathered}
\mathrm{EDF}=\operatorname{Pr}\left(\mathrm{E}\left(V_{1}\right)<D P\right) \\
=N\left[\left(D P-\mathrm{E}\left(V_{1}\right)\right) /\left(E\left(V_{1}\right) \sigma_{A}\right)\right]=\mathrm{N}(-\mathrm{DD})
\end{gathered}
$$

- $\quad$ Expected loss

Expected loss $=$ Loss Given Default $\times$ Exposure at Default

The above gives explanation about the parameter in the model we used in this paper.

\section{CREDIT RISK MITIGAT ION PRICING EMPIRICAL ANALYSIS}

\section{A. pricing entity choice}

The KMV model is appropriate in pricing short term asset. And the time series data we choose is from Jan 2010 to Dec 2010. So we choose the first round short term financial bonds of Heilongjiang Agriculture Company Limited as

\begin{tabular}{|c|c|c|c|}
\hline Name & \multicolumn{3}{|c|}{\begin{tabular}{|c|} 
the first round short term financial bonds of \\
Heilongjiang Agriculture Company Limited in 2011
\end{tabular}} \\
\hline Bond ticker & 1181011 & End of issue day & 2011-01-13 \\
\hline Issue date & 2011-01-13 & Issue market & Interbank market \\
\hline Public date & 2011-01-14 & Issue company & \begin{tabular}{|l|} 
Heilongiiang \\
Agriculture \\
Company Limited \\
\end{tabular} \\
\hline $\begin{array}{|ll|}\begin{array}{l}\text { Volume } \\
\text { RMB) }\end{array} & \text { (trillion } \\
\end{array}$ & 5.0000 & & \\
\hline Face value (RMB) & 100.00 & $\begin{array}{l}\text { Repayment of } \\
\text { capital and interest }\end{array}$ & Fixed interest \\
\hline Issued price & 100.00 & Issuance ways & Dutch bidding \\
\hline Term (year) & 1 & Maturity date & 2012-01-13 \\
\hline $\begin{array}{l}\text { Yearly } \\
\text { rate (\%) }\end{array}$ & 4.43 & Credit rating & A-1 \\
\hline
\end{tabular}
underlying assets which is shown in Tab.2. Heilongjiang Agriculture Company Limited is a public company with high credit rating. As a leading company in this industry, it is appropriate to meet the KMV analys is standards.

TABLE II. THE BASIC INFORMATIONOF 11AGRICULTURE CP01

B. 4.2 Empirical calculations

\section{1) Default point calculation}

Tab.3 shows part of Heilongjiang Agriculture Company Limited's balance sheet with a total debt of 12030641425

\begin{tabular}{|c|c|c|c|}
\hline Short term debt & amount & Long term de bt & Amount \\
\hline Short term loan & 7127195897 & Long term loan & 12257152 \\
\hline Notes payable & 77200000 & Bonds payable & 800000000 \\
\hline Account payable & 1083052106 & $\mid \begin{array}{ll}\text { Long } & \text { term } \\
\text { payable } & \end{array}$ & 137271.31 \\
\hline $\begin{array}{l}\text { Deposits } \\
\text { received }\end{array}$ & 2156364898 & $\begin{array}{l}\text { Other illiquid } \\
\text { debt }\end{array}$ & 60138228 \\
\hline Wages payable & 252295980.1 & $\begin{array}{l}\text { Total long term } \\
\text { debt }\end{array}$ & 872532652 \\
\hline Taxes payable & -637417337.1 & & \\
\hline Interest payable & 33108522.98 & & \\
\hline Bonus payable & 387613.38 & & \\
\hline Other payables & 1065921093 & & \\
\hline $\begin{array}{l}\text { Total short term } \\
\text { debt }\end{array}$ & 11158108773 & & \\
\hline
\end{tabular}
$\mathrm{RMB}$, in which $11158108773 \mathrm{RMB}$ is short term debt and $872532652 \mathrm{RMB}$ is long term debt.

As calculated in formula (5):

$$
\mathrm{DP}=\mathrm{STD}+0.5 \mathrm{LTD}=11158108773
$$

TABLE III. TheAgricultureDeBt Unit: RMB

2) Default distance calculation

\section{a) Standard error of equity return calculation}

Heilongjiang Agriculture Company Limited has a volume of 1777679910 shares of equity. Based on history volatility model, we assume share price follow logarithm normal distribution, then we can get the daily rate of return:

$$
\mu_{i}=\ln \left(S_{i} / S_{i-1}\right)
$$


$\mathrm{S}_{\mathrm{i}}$ is the closing price on the $\mathrm{i}^{\text {th }}$ day, and then the daily rate of return standard error is:

$$
\sigma_{E}^{\prime}=\sqrt{\frac{1}{\mathrm{n}-1} \sum_{i=1}^{n}\left(\mu_{i}-\bar{\mu}\right)^{2}}
$$

$\bar{\mu}$ is the expectation of daily rate of return, that is $\bar{\mu}=$ $\frac{1}{\mathrm{n}} \sum_{i=1}^{n} \mu_{i}$

Given the number of trading days, the yearly standard error is $\sigma_{E}=\sigma_{E}^{\prime} \sqrt{T}$

With 235 trading days, Heilongjiang Agriculture Company Limited has a 0.121789 yearly volatility. The standard error of equity rate of return is 0.348983 .

b) Value of equity

The average share price of Heilongiang Agriculture Company Limited during 2010 is 13.64 RMB. With 1777679910 shares, the market capitalization is 24247553972.4 RMB.

c) Asset value volatility

Solve the following nonlinear function group

$$
\begin{gathered}
\because \mathrm{E}=\mathrm{VN}\left(\mathrm{d}_{1}\right)-\mathrm{De}^{-\mathrm{rt}} \mathrm{N}\left(\mathrm{d}_{2}\right) \\
\sigma_{E}=\frac{N\left(d_{1}\right) V}{E} \sigma_{A} \\
\mathrm{~d}_{1}=\frac{\ln \left(\frac{\mathrm{V}}{\mathrm{D}}\right)+\left(\mathrm{r}+\frac{1}{2} \sigma_{\mathrm{A}}^{2}\right) \tau}{\sigma_{\mathrm{A}} \sqrt{\tau}} \\
d_{2}=d_{1}-\sigma_{A} \sqrt{\tau}
\end{gathered}
$$

With DP $=11594375098, E=24247553972.4, \tau=1$ year, and $\sigma_{\mathrm{E}}=0.348983$, we can get

$$
\sigma_{\mathrm{A}}=0.238, \mathrm{~V}=35556000000
$$

Then with (6), we get a $\mathrm{DD}=2.8316$

\section{3) EDF and EL calculation}

From $(7)$, we know EDF $=\mathrm{N}(-\mathrm{DD})=0.0023$

In this paper we use loss given default gathered by Chinese scholars to calculate expected loss as showed in Tab.4. LGD for Heilongjiang Agriculture Company Limited is $30.57 \%$ since it is credit debt.

TABLE IV. THE LGD VALUATION

\begin{tabular}{|l|l|l|l|l|}
\hline $\begin{array}{c}\text { Type of } \\
\text { bond }\end{array}$ & $\begin{array}{c}\text { Mortgaged } \\
\text { debt }\end{array}$ & $\begin{array}{c}\text { Secured } \\
\text { debt }\end{array}$ & $\begin{array}{c}\text { Mortgaged and } \\
\text { secured debt }\end{array}$ & $\begin{array}{c}\text { Credit } \\
\text { debt }\end{array}$ \\
\hline LGD & $34.76 \%$ & $37.10 \%$ & $34.05 \%$ & $30.57 \%$ \\
\hline
\end{tabular}

So, $\mathrm{EL}=\mathrm{LGD} * \mathrm{EAD}=152850000 \mathrm{RMB}$

\section{4) CRM pricing}

From(1), we know that

$$
\omega=\mathrm{i}-\mathrm{r}=-\frac{1}{T} \cdot \ln \left(1-\frac{E D F \cdot E L}{F_{T}}\right)=0.0007
$$

So the price of CRM which is based on the first round short term financial bonds of Heilongjiang Agriculture Company Limited in 2011 is about 7 basis points.

\section{CONCLUSIONS}

Credit spread method can make the CRM pricing process simpler, and KMV model can reduce our dependence on history data. Such combination is appropriate for the current state of market in China. The scale of CRM market now is relatively small in its beginning period. To perfect this market, we need to build central clearing system, promote trading standardization, and improve the concentration of information. But also, the regulation cannot be too heavy which may suppress the market development. It needs to take step by step to enrich the derivative market focusing on simple and interbank product first.

\section{Acknowledgment}

Sincere thanks to the authors of the thesis quoted and referred to in this paper and the anonymous reviewer's amendment advice. The author is responsible for the opinions and conclusions of this paper.

\section{REFERENCES}

[1] Ming Wei, Qiong Wang. The Credit Derivatives' Functionin Our Country's Credit Risk Management Its Implementation Strategies [J]. Management World, 2003(10).

[2] Jianjun Wang. To Redefine and Reposition Credit Risk Mitigation[J]. World Economic Outlook, 2008(9).

[3] Dan Feng.The Innovation and Development of Yuan Credit Risk Mitigation [J]. China Finance, 2010(22).

[4] Ling Zhang, Guilin Zhang. Development of Credit Risk Measurement Methodology[J]. Forecasting 2000(4).

[5] Wei Lu, Hengheng Zhao, Zhaoben Fang, Jiyun Liu.KMV Model Applied in Corporate Asset Valuation[J]. Policy-making Reference, 2003(3)

[6] Nengfu Zhang, Jia Zhang.The Application of Amended KMV Model in Measuring Credit Risk of China Listed Companies[J]. Forecasting, 2010(5).

[7] WenhanYang, Yan Yang. Credit Default Swap Pricing Model and Empirical Study[J]. Stat istics and Decision. 2005(8).

[8] Wei Zhang. Credit Default Swap Pricing Model and Empirical Study [D].Capital University of Economics and Business, 2010.

[9] JUN YANG, Jian CHENG, JunwU PAN. A Theoretical and Empirical Study on LGD Models [J]. Studies of International Finance, 2009(6). 